\title{
Ludobójstwo w świetle wybranych relacji więźniów obozów koncentracyjnych Auschwitz, Majdanek, Stutthof i Gross-Rosen
}

\author{
Genocide in the Light of Selected Accounts by Concentration Camp Prisoners \\ of Auschwitz, Majdanek, Stutthof, and Gross-Rosen
}

\begin{abstract}
Aвstract: The article is devoted to the analysis of testimonies, accounts, memoirs, ego-documents by concentration camp prisoners of Auschwitz, Majdanek, Stutthof, and Gross-Rosen. The source material kept in the said KLs' archives contains a multitude of individual histories of survivors of the genocide, either described in detail or concisely noted down. What the author focuses on is the variety of those testimonies to suffering and tragedy of people incarcerated in concentration camps. At the same time, she observes that for the former prisoners, decades after leaving the camps, the Shoah and hell are synonymous with genocide. The most common terms used by them to describe genocide are: mass extermination, the Holocaust, Annihilation, hell, the Shoah, hideous violence, total annihilation - both physical and moral.
\end{abstract}

KEY WORDS: memories, relations, testiemonies, genocide, archives of concentration camps

W artykule nie będzie mnie interesować ani żadna określona teoria związana z historycznym bądź współczesnym rozumieniem ludobójstwa, ani analizowanie jego - niewątpliwie częstych i znacznych - narracyjnych świadectw. Zastanawiam się nad zestawieniem jednostek dla badań nad genocydami elementarnych, takich jak ich określenia językowe, oraz możliwościami deskryptywnymi

* Artykuł powstał w ramach realizacji grantu Miniatura 2 przyznanego przez Narodowe Centrum Nauki na projekt "Rola czytelnictwa w wybranych obozach koncentracyjnych - zebranie materiałów źródłowych", nr rej. 2018/02/X/HS2/01015. 
owych określeń, ułatwiającymi poszczególnym osobom identyfikację własnych przeżyć i przeżyć otoczenia. Interesuje mnie też sam stan archiwów obozowych, możliwość poszukiwania w nich śladów tego, jak ludzie nazywali zjawisko ludobójstwa i czy takie dokumenty osobiste w ogóle się zachowały.

Fragmenty relacji więźniów obozów koncentracyjnych, które przytaczam w artykule o ściśle źródłowym charakterze, zawierają niektóre z powszechnie używanych przez nich słów określających znaczenie pojęcia „ludobójstwo” i konteksty, w jakich je stosowano. Zaprezentowane wspomnienia i relacje ofiar, Żydów oraz Polaków, wchłoniętych przez niosące śmierć wydarzenia w sam środek masowych mordów, stanowią jedynie znikomą część świadectw byłych więźniów obozów koncentracyjnych i nieledwie przyczynek do badań nad kwestią stosowania wspomnianego terminu ${ }^{1}$. Analiza opiera się na wszystkich materiałach znalezionych podczas kilkudniowej kwerendy w archiwach muzeów powstałych na terenach obozów koncentracyjnych: Auschwitz, Majdanek, Stutthof i Gross-Rosen². Brak podziału tekstów zeznań ofiar według poszczególnych obozów koncentracyjnych wynika ze skoncentrowania analiz wokół stwierdzenia, że „Zagłada” i „piekło” to najczęstsze synonimy ludobójstwa, stosowane niezależnie od preferencji kulturowych użytkowników języka. Występują one również jako parafrazy czy metafory genocydu. Udzielenie odpowiedzi na pytanie, czy użycie takiego, a nie innego określenia nie zależy na przykład od poziomu wykształcenia danej osoby, a nie tylko jej obozowych doświadczeń, wydaje się zadaniem wymagającym osobnego opracowania.

Rozważania nad epoką nazistowską - jak zauważyła Doris L. Bergen ${ }^{3}$ rodzą drażliwe problemy terminologiczne. Również wprowadzanie przez badaczy własnych definicji ludobójstwa wywołuje pojęciowy chaos ${ }^{4}$. W artykule podejmę próbę zaprezentowania określeń, jakimi posługiwali się byli więźniowie

${ }^{1} \mathrm{O}$ wprowadzeniu do języka polskiego pojęcia „genocidium”, którego twórcą był Rafał Lemkin, jako „ludobójstwo” zob. K. DAszKIEWICZ: Niemieckie ludobójstwo na narodzie polskim (1939-1945). Toruń 2009, s. 11-13. Rozróżnienia między ludobójstwem a genocydem dokonała niedawno Anita Jarzyna, tłumacząc, że pierwsze słowo ma dość wąski zakres znaczeniowy, ograniczony w zasadzie całkowicie do doświadczeń ludzi. Natomiast genocyd, pochodzący od greckiego génos - 'rasa', ma zakres szerszy, którym obejmuje się też doświadczenia nieludzi, m.in. zwierząt (badaczka wspomina o tym w kontekście masakry stambulskich psów w 1910 r.). Por. A. JARzYNA: Post-koiné. Studia o nieantropocentrycznych językach (poetyckich). Łódź 2019, s. 131-132.

${ }^{2}$ Kwerendy przeprowadzono w drugiej połowie 2019 r. Za życzliwą pomoc dziękuję dr Danucie Drywie, kierownik Działu Dokumentacyjnego Muzeum Stutthof w Sztutowie, dr. Wojciechowi Płosie, kierownikowi Archiwum Państwowego Muzeum Auschwitz-Birkenau w Oświęcimiu, Leokadii Lewandowskiej i Anecie Małek z Działu Gromadzenia Zbiorów Muzeum Gross-Rosen.

${ }^{3}$ Doris L. Bergen wskazuje na wątpliwości dotyczące używania pojęć „naziści” czy „Niemcy", kiedy mowa o okresie rządów Hitlera w Niemczech. Zob. D.L. Bergen: Wojna i ludobójstwo. Krótka historia Holokaustu. Przeł. R. Witкowski, M. Sosnowski. Poznań 2011, s. 10.

${ }^{4} \mathrm{Na}$ pojęciowy chaos związany z ludobójstwem, który wykorzystują politycy, mobilizując wyborców w czasie debat o przyszłości, wskazuje Lech M. Nijakowski. Zob. Tenże: Ludobójstwo. Historia i socjologia ludzkiej destrukcji. Warszawa 2018, s. 11-12. 
po kilkudziesięciu latach od opuszczenia obozów koncentracyjnych. Chodzi mi także o to, by zwrócić uwagę, w jaki sposób opowiadają oni o traumie i praktykach ludobójczych. Interesują mnie ślady masowej zbrodni utrwalone $\mathrm{w}$ ich pisemnych relacjach. Określenie „ludobójstwo” pojawiło się w 1944 roku $^{5}$, więc teoretycznie znano je zarówno podczas wyzwolenia lagrów, jak i po wojnie, gdy składano najwięcej relacji. Wydaje się, że ofiary, które przetrwały „czasy pogardy”, miały możliwość zapoznania się ze wspomnianą kategorią i stosowania jej, przynajmniej teoretycznie, w swoich wspomnieniach, sprawozdaniach, egodokumentach.

Już pierwsza kwerenda przeprowadzona w Archiwum Państwowego Muzeum Auschwitz-Birkenau przyniosła zaskakujące rozstrzygnięcia. Wyszukiwanie w jego bazie słowa „ludobójstwo” pokazało, że w jej zasobach nie występuje takie pojęcie. Podobnie było w archiwach Gross-Rosen, Stutthofu i Majdanka. Wśród najczęściej stosowanych w relacjach więźniów obozów określeń ludobójstwa pojawiały się natomiast: masowa zagłada, Holokaust, Zagłada ${ }^{6}$, piekło, Szoa, ohydna przemoc, terror ${ }^{7}$, „Zagłada totalna - fizyczna i moralna, realizowana sukcesywnie, aby maksymalnie wykorzystać pracę więźniów" archiwistami - pracownikami Muzeum Auschwitz, którzy spotykali się w latach 90. XX wieku na terenie Polski i Izraela z więźniami - stwierdzić więc można, że słowo „ludobójstwo" nie występuje bezpośrednio, za to pojawiają się jego synonimy lub parafrazy.

Kierownik Archiwum Państwowego Muzeum Auschwitz-Birkenau Wojciech Płosa zasugerował, by w pierwszej kolejności przeanalizować wypowiedzi

${ }^{5}$ Termin „ludobójstwo” (ang. genocide, który później został przetłumaczony jako „ludobójstwo") wprowadził polski prawnik Rafał Lemkin w swojej pracy Axis Rule in Occupied Europe wydanej w 1944 r. w USA. Użyto go w akcie oskarżenia w procesie norymberskim przeciwko przywódcom nazistowskich Niemiec. Warto zaznaczyć, że Karta Międzynarodowego Trybunału Wojskowego w Norymberdze nie wymieniała wprost ludobójstwa, lecz jedynie zbrodnie przeciwko ludzkości (zob. J. BiaŁocerkiewicz: Prawo międzynarodowe publiczne. Zarys wykładu. Toruń 2007, s. 462), których kwalifikowaną postacią jest właśnie ludobójstwo. Do języka prawnego termin „ludobójstwo” wszedł za sprawą Konwencji ONZ w sprawie Zapobiegania i Karania Zbrodni Ludobójstwa podpisanej 9 grudnia 1948 r., której wstępny projekt był współtworzony przez Rafała Lemkina.

${ }^{6} \mathrm{O}$ terminach odnoszących się do zagłady Żydów szerzej pisali M. AdAmczyk-GarbowSKA, H. DUdA: Terminy „Holocaust”, "Zagłada” i "Szoa” oraz ich konotacje leksykalno-kulturowe w polszczyźnie potocznej i $w$ dyskursie naukowym. W: Żydzi i judaizm we wspótczesnych badaniach polskich. T. 3. Red. K. Pilarczyk. Kraków 2003, s. 237-253.

„Rozpoczął się terror... [...] Wydawało mi się, że nie ma dla mnie żadnej nadziei - że to już koniec wszystkiego” (S. ŁотоскA: „Ci, którzy działali na rozkaz” (relacja). Archiwum Państwowe Muzeum na Majdanku. Sygn. VII/Z-18, s. 1).

${ }^{8}$ Eugenia PIwińska w relacji zatytułowanej „Ruch oporu na polu kobiecym w obozie na Majdanku” dodaje, że: „Wobec tego walka w obozie sprowadzała się do walki o życie, świadomej lub instynktownej, do obrony wydartego przez warunki i terror człowieczeństwa i ludzkiej godności” (Archiwum Państwowe Muzeum na Majdanku. Sygn. VII/M-210, s. 1). 
więźniów pracujących na rampie, gdyż widzieli oni selekcje ${ }^{9}$ i masową zagładę. W ich relacjach brakuje jednak wprost wyartykułowanego słowa „ludobójstwo”. Powraca motyw bezsilności wobec ludzkiego cierpienia. Byli więźniowie precyzyjnie opisują ludobójcze techniki sklasyfikowane przez Lemkina ${ }^{10}$ : społeczne, kulturowe, biologiczne, fizyczne, polityczne, religijne, moralne, ekonomiczne.

Ostatnia wstępna uwaga dotyczy kwestii przytoczonego $\mathrm{w}$ artykule materiału: czasami relacje mówią więcej o ludziach, którzy je przedstawiają, niż o tych, którzy byli oprawcami ${ }^{11}$. Zacytujmy obszerny fragment zapisu:

Byłem w podniosłym nastroju, niemal w euforii. Jestem wolny, wolny, wolny. Znów wolny po pięciu i pół latach ciągłego zagrożenia życia, nieustannego strachu, strasznego głodu. Mogę pójść, dokąd zechcę, postępować zgodnie z moją wolą, nie znajduję się więcej za drutami kolczastymi, pilnowany przez uzbrojonego żołnierza. Nikt mi więcej nie grozi pobiciem i nie krzyczy na mnie. Zwyciężyłem, stał się cud, dzięki nadzwyczajnemu splotowi okoliczności ja pozostałem przy życiu, kiedy moi najbliżsi zginęli. Niemcy zamordowali moich rodziców, większość członków rodziny, kolegów i znajomych - a ja żyję. W końcu sprawiedliwość zwyciężyła, Hitler został pokonany. Ludzkość nie pozostanie już taka jak dotąd. Świat zostanie wstrząśnięty straszliwą zbrodnią, której na nas dokonano i stanie się lepszy. Nie miałem pojęcia, jaka będzie moja przyszłość, ale wierzyłem, że na pewno będzie dobra ${ }^{12}$.

Analizując wypowiedzi ofiar ludobójstwa, wiele można dowiedzieć się o ich poczuciu zagubienia i obawach. Ujawniają też te słowa pewne schematy myślenia, lęk o życie "gorszej rasy zwierzęcia ludzkiego"13.

${ }^{9}$ Częstotliwość i skala przeprowadzanych selekcji powodowały, że obozowe krematoria dosłownie zapychały się. „Był to początek nasilającej się fali pośpiesznej likwidacji Żydów. Selekcje stały się tak częste, że krematorium nie nadążało z paleniem zwłok. I wtedy rozpoczęto palenie ciał pod gołym niebem. Nad Majdankiem snuły się gęste dymy zaciemniające horyzont, a mdlący zapach, od którego pękała głowa, zbierało się na torsje, traciło apetyt, sen i chęć do życia, przenikał cały obóz - w dzień i w nocy" (tamże, s. 28).

${ }^{10}$ R. Lemkin: Rządy państw Osi w okupowanej Europie. Prawa okupacyjne, analiza rzadzenia, propozycje zadośćuczynienia. Przeł. A. Bieńczyk-Missala i in. Warszawa 2013, s. 113-120.

${ }^{11}$ Zdarzają się relacje, w których niejako punktem odniesienia dla ofiar są ich oprawcy. „Niemcy - SS-mani w obozie nie zasługiwali na to, aby ich nazywać ludźmi. [...] Tych wszystkich Niemców można określić jako bestie, dzikie zwierzęta, które ze złośliwością kota bawiącego się z myszką zadawały katusze przed śmiercią. Tkwił w nich instynkt sadyzmu, może nawet odczuwali pewnego rodzaju przyjemność w pastwieniu się nad ludźmi. Szczególnie lubili się znęcać nad tymi, którzy się bali, płakali, prosili o litość" (L. Duszyński: Relacja z 15 kwietnia 1964 r. W: Relacje. T. 2. Archiwum Muzeum Stutthof, s. 134).

${ }^{12}$ C. Werebejczyk: „Rozterki i rozczarowania. Wspomnienia z Polski. Czerwiec 1945-kwiecień 1957”. W: Wspomnienia. T. 240. Państwowe Muzeum w Oświęcimiu. Nr inw. 181327. Sygn. Wsp./Werebejczyk/1374, s. 3-4.

${ }^{13}$ Sformułowanie zaczerpnęłam z charakterystyki polityki rasistowskiej zamieszczonej w publikacji: J. Guмкоwsкi, T. KuŁa коwsкi: Zbrodniarze hitlerowscy przed Najwyższym Trybunałem Narodowym. Warszawa 1961, s. 28. 
Kara chłosty, maltretowanie, odrywanie od matek i zabijanie dzieci, przeprowadzanie selekcji, bestialskie przesłuchania, eksperymenty pseudomedyczne, ograniczanie racji żywnościowych, wyroki śmierci przez powieszenie wykonywane przy akompaniamencie orkiestry, masowe egzekucje, spalanie zwłok w krematoriach, popisy „szkoły Gladiatorów”" ${ }^{14}$ z Gross-Rosen, w której uśmiercano więźniów - to tylko nieliczne $\mathrm{z}$ wymyślnych narzędzi ${ }^{15}$ służących do masowego torturowania uwięzionych.

Wydaje się, że wypowiedzi więźniów są racjonalnymi, nie tyle rejestrującymi, ile podsumowującymi obiektywnie istniejącą rzeczywistość drutów kolczastych wywodami. Zaprezentowane w dalszej części artykułu wyimki relacji zniewolonych wypływają z doświadczenia czasu ludobójstwa; nie są one oparte na wyobrażeniach czy zasłyszanych historiach o zdarzeniach, których dotyczą. Bezbłędnie oddają natomiast charakter i znaczenie ludobójstw drugiej wojny światowej, bez użycia prawniczego żargonu, bez instrumentarium naukowego i perspektywy politologicznej, socjologicznej, filozoficznej czy historycznej. To nieuświadomiony przez składających zeznania rejestr metod, technik i procesów, które prowadzą do masowej eksterminacji. We Wspomnieniach z okresu Zagłady Chanan Werebejczyk podkreślał, że:

W czasach ghetta i obozów koncentracyjnych, bywało bardzo ciężko, tak źle, że nawet nam samym, którzy byliśmy tam, trudno było uwierzyć, że to, co przeżywamy, jest rzeczywistością. Ludzie wtedy mówili: „Jeśli pozostaniemy przy życiu, opowiemy o wszystkim, całą prawdę, żeby świat wiedział”. Sądziliśmy, że świat nie wie, co się u nas dzieje i dlatego nie reaguje. Teraz wiemy, jak naiwne było to przekonanie. Świat wiedział i milczał ${ }^{16}$.

Obowiązkiem ocalałych ${ }^{17}$ powinno być utrwalanie pamięci o ofiarach ludobójstwa, gdyż niewiedza i obojętność mogą prowadzić do kolejnych zagrożeń. Czy jednak w ogóle można było pojąć, co się działo w obozach? A w jaki sposób współcześnie powinno się opisywać to, co rozgrywało się tam i wtedy? Odpo-

14 M. MoŁdawA: Gross-Rosen. Obóz koncentracyjny na Ślasku. Warszawa 1967, s. 163.

15 „A więc choroby, bicie, katorżnicza praca, załamanie psychiczne i głód dziesiątkowały więźniów, żniwo śmierci było zastraszające, dziennie kilka stosów po kilkaset więźniów paliły się [...]. Słowo człowiek to jakiś zapomniany termin, to sen, tu był tylko łachmanem szczutym na każdym kroku, pozbawiony nazwiska, poniewierany przez takich samych stworzeń jak i on, którego celem było drugiego zabić, by samemu w tym piekle żyć. [...] Diabeł w piekle w porównaniu z SS-manami to anioł. Więzień więźnia zabija po to, by jego porcję chleba zjeść" (J. ZAKRZEWSKI: „A my żyjemy dalej... Wspomnienia więźnia”. Archiwum Państwowe Muzeum na Majdanku. Sygn. VII/M-6, s. 32).

16 C. Werebejczyк: „Wspomnienia z okresu Zagłady”. W: Wspomnienia. T. 240..., s. 1.

17 Warto przywołać fragment Innego świata... Gustawa Herlinga-Grudzińskiego: „Mów całą prawdę, jacyśmy byli, mów, do czego nas doprowadzono” (TENżE: Inny świat. Zapiski sowieckie. Przedm. B. Russel. London 1953, s. 128). 
wiedzi na pytania, dotykające problemu natury egzystencjalnej, pośrednio zawarte są w przytaczanych fragmentach świadectw. Trzeba przy tym pamiętać, że ludzie mają skłonność do przesadnego podkreślania własnych cierpieńn ${ }^{18}$. Dalsza część relacji Werebejczyka, która rejestruje skoordynowany plan różnorodnych działań mających na celu unicestwienie wybranych grup - Polaków i Żydów, wymaga przyjrzenia się przyczynom strachu:

Od pierwszej chwili po wkroczeniu wprowadzili Niemcy atmosferę terroru. Aresztowali i mordowali działaczy społecznych, intelektualistów, dziennikarzy - Polaków i Żydów. Wszyscy byli zastraszeni. My baliśmy się przede wszystkim dlatego, że Żydzi z miejsca stracili wszelkie prawa obywatelskie. Każdy, kto miał chęć, mógł Żyda obrabować, zbić, zabić, wyrzucić z mieszkania [...]. Na ulicach ciągłe łapanki. Zabierali przechodniów do różnych robót $[\ldots]^{19}$.

Poszczególne wspomnienia i zeznania wchodzą ze sobą w nieoczekiwane interakcje, tworząc ciąg zdarzeń nabierających czasem wręcz symbolicznych i uniwersalnych znaczeń. Opis przez więźniów „technik ludobójstwa na różnych polach" ${ }^{20}$ charakteryzują autentyzm, surowość relacji, dokumentaryzm.

Wyjątkowo wybrzmiewają w zeznaniach momenty, kiedy opadały wszelkie złudne nadzieje na ocalenie. Świadomość zagłady nie zawsze była impulsem do stawiania oporu architektom „ostatecznego rozwiązania”.

Po raz pierwszy Niemcy działali w ghecie bez żadnych osłonek, nie robili iluzji, nie opowiadali uspakajających historyjek. Było jasne, że zabierają ludzi na śmierć2 ${ }^{21}$.

Ludobójstwo oparto na prostych zasadach:

W sierpniu 1944 ghetto zostało zlikwidowane, wszyscy mieszkańcy wywiezieni w wagonach bydlęcych do Oświęcimia. Ludzie starsi, chorzy, dzieci, matki z dziećmi szli od razu do gazu i na spalenie. Reszta poszła do obozu i ginęła ${ }^{22}$.

18 „Przez dziesięciolecia toczyła się w Polsce (nierówna) walka o "palmę męczeństwa« między Polakami i Żydami. W PRL "zapominano«, że Żydzi (nie tylko polskiego pochodzenia) ginęli z rąk Niemców przede wszystkim jako Żydzi, nie zaś jako Polacy (względnie obywatele polscy)" (A. Morawiec: Literatura polska wobec ludobójstwa. Rekonesans. Łódź 2018, s. 18-19). Mówi na ten temat także Irit Amiel w rozmowie zamieszczonej w niniejszym numerze „Narracji o Zagładzie”, por. „[...] sprowadzić na świat nowe dzieci, za tamte, spalone”. Z Irit Amiel o życiu i pisaniu rozmawia Marta Tomczok (s. 28-36).

19 C. WerebejCzyK: „Wspomnienia z okresu Zagłady”..., s. 8.

${ }^{20}$ R. Lemkin: Rządy państw Osi..., s. 113-120.

${ }^{21}$ C. WerebejCzy K: „Wspomnienia z okresu Zagłady”..., s. 27.

22 Tamże, s. 34. 
Jednocześnie zastosowano kilka ludobójczych technik: dyskryminację rasową w żywieniu, tworzenie złych warunków życia, pozbawianie możliwości zachowania zdrowia, masowe zabijanie, wysiedlenie sukcesywnie niszczące podstawy życia ekonomicznego grupy, obniżenie standardu życia, konfiskaty mienia.

Wypowiedzi świadków, tych, którzy wymknęli się zagładzie, ukazują i odkrywają złożoność sytuacji kryzysowych. Zdają się także uniwersalizować jednostkowe przeżycia więźniów obozów koncentracyjnych, łącząc je z innymi zbrodniami oraz opresjami związanymi z ludobójstwem.

$\mathrm{W}$ relacji z pobytu $\mathrm{w}$ getcie w Łodzi oraz w obozach koncentracyjnych w Auschwitz, Sachsenhausen i Mauthausen, złożonej w Tel Awiwie 2 listopada 1995 roku, Chaim Piotrowski zauważył, że:

W związku z tym nie spieszyłem się poddać dalszej procedurze przejęcia nas przez miejscową załogę SS. Zauważyłem, że jesteśmy ustawiani w jakiś szczególny sposób i za chwilę będę musiał temu się podporząakować, zatrzymałem się jednak na chwilę, gdyż z natury lubię się rozglądać. Stanąłem przy grupie esesmanów, którzy przyjechali z nami jako konwojenci naszego transportu. Obok nich stali dwaj miejscowi esesmani. Zawiązała się między nimi rozmowa, którą w części dosyć dokładnie wysłuchałem. Esesman z konwoju powiedział do jednego z miejscowych esesmanów: „Zobacz. Jaka ładna młodzież! Chłopcy i dziewczęta i Dzieci takie ładne! I pan mówi, że oni idą na zagładę? Czy to nie szkoda?”. Miejscowy esesman odpowiedział: „Dureń jesteś. Jak ty możesz tak myśleć? Pomyśl o naszej młodzieży ze Stalingradu. Pomyśl o naszej młodzieży, która teraz walczy z Rosjanami nad Wisłą. Pomyśl jak idzie tysiącami na zagładę. I ty teraz litujesz się nad Żydami? ${ }^{23}$

Ofiarom ludobójstw - o czym pisano wielokrotnie - odbierano przede wszystkim tożsamość i człowieczeństwo. Choć składający zeznania przedstawiają losy narodów i doświadczenia zbrodni, to jednak są to historie jednostkowe ${ }^{24}$, przypadki pojedynczych ludzi, ich osobiste, tragiczne doświadczenia i przeżycia zaprezentowane z perspektywy ocalałego. Czasami opowiadający próbuje przekonać siebie i osobę notującą zeznania, że należy odrzucić stereotyp winnego i przyznać prawo do człowieczeństwa, które chcieli mu odebrać ludobójcy.

Stwierdzenie, że „w pierwszych latach po wojnie wracały czasem w nocy przeżyte kiedyś koszmary. [...] A jednak, mimo pozorów, wspomnienia z okresu

${ }^{23}$ Relacja Chaima Piotrowskiego (ur. 13 stycznia 1927 r. w Łodzi) z 2 listopada 1995 r. w Tel Awiwie. Państwowe Muzeum w Oświęcimiu. Nr inw. 174724. Sygn. Ośw./Piotrowski/3180, s. 5.

${ }^{24}$ Warto przywołać w tym miejscu uwagę Michała GŁowińskiego: „[... ] literatura bowiem nie opowiada o tym, co masowe, jej nieustannym przedmiotem jest los jednostkowy" (TenżE: Kapuściński: reportaż jako sztuka. W: „Życie jest z przenikania...”. Szkice o twórczości Ryszarda Kapuścińskiego. Zebrał i oprac. B. WróBlewski. Posłowie A. KapuścińsKa. Warszawa 2008, s. 64). 
Szoah rzucają cień na całe moje życie"25, dowodzi, że ludobójstwo wyzwoliło w ocalonych pamięć totalną. O życiu „w cieniu Zagłady” czy w „długim cieniu Zagłady" napisano już zresztą bardzo wiele ${ }^{26}$; oddziaływanie ludobójstwa na całe późniejsze życie ocalonych widać najwyraźniej właśnie w tych, nieco już dziś skostniałych, stereotypowych określeniach, które jednak w świadectwach pierwszego stopnia oznaczają zupełnie co innego niż w narracjach współczesnych. Wskazują bowiem na ograniczenia języka, wieloznaczność słów kluczowych, wręcz niejęzykowość samego ludobójczego doświadczenia.

Autorzy relacji, byli więźniowie, zdają sobie sprawę, że w narracjach osobistych ukazują niekiedy bezduszne mechanizmy ludobójstwa, nie potrafiąc wiele więcej napisać na ich temat, nie rozumiejąc szczegółowo opisywanych zdarzeń ani rządzących nimi praw:

[...] Nie mieliśmy dosyć czasu, żeby ten okres getta dokładniej omówić, żeby poznać technikę, jaką Niemcy prawie dwieście tysięcy ludzi potrafili wyniszczyć, stosując metody zagłodzenia, „ewakuowania” i mordowania w pierwszej kolejności dzieci i starców ${ }^{27}$.

W kilku wspomnieniach znalezionych podczas kwerendy pojawiają się konkretne liczby ${ }^{28}$ ofiar masowych zbrodni. Nie one jednak odzwierciedlają naturę ludobójstwa, choć umożliwiają zrozumienie jego skali.

Bywały dni, że umierało dziennie 400-500 więźniów. Krematorium nie nadążało w paleniu zwłok. Czynny był stos całopalny [...]. Widok palonych

${ }^{25}$ C. Werebejczyк: „Wspomnienia z okresu Zagłady”..., s. 61.

${ }_{26}$ Por. m.in. F. Tych: Dlugi cień Zagłady. Warszawa 1999.

${ }^{27}$ Relacja z 5 listopada 1995 r. złożona w Tel Awiwie przez Zeewa Factora (ur. 5 kwietnia 1926 r. w Łodzi), sekretarza Generalnego Związku Łodzian w Izraelu. Factor dał świadectwo swoich przeżyć podczas Holokaustu, z pobytu w getcie w Łodzi oraz w obozach koncentracyjnych Auschwitz (gdzie był oznaczony numerem obozowym B-7594 i ponad dwa miesiące spędził w podobozie Wirtschaftshof Birkenau), Gross-Rosen (podobóz Bolkenhein) i Buchenwald (Państwowe Muzeum w Oświęcimiu. Nr inw. 174723. Sygn. Ośw./Factor/3179, s. 20).

${ }^{28}$ W protokole przesłuchania Danuty Brzosko-Mędryk z 1967 r. czytamy: „[...] pamiętam, że w dniu 3 listopada 1943 r. widziałam osobiście jak wymieniony już wcześniej Anton Thuman zabił z pistoletu przed obrębem I-go pola najpierw mężczyznę idącego w szeregu więźniów, a następnie zabił kobietę, również więźniarkę. Ja znajdowałam się wówczas przy bloku »funkcyjnych" w odległości kilkudziesięciu metrów. Data 3 listopada 1943 r., kiedy zabójstwa te miały miejsce utkwiła mi szczególnie w pamięci z tego powodu, że była to na Majdanku tzw. »krwawa środa«, kiedy to hitlerowcy zastrzelili około 18000 Żydów" (Archiwum Państwowe Muzeum na Majdanku. Sygn. VII-135/160, s. 3). To samo wydarzenie opisała Matylda Woliniewska w zeznaniu zatytułowanym „Przeciw przemocy. Totalna zagłada i upodlenie śmierci”: „To na zawsze pozostanie w pamięci [...]. W listopadzie 1943 r. rozstrzelano na Majdanku kilkanaście tysięcy Żydów. Pozostał po nich kopiec prochu, zabawki dziecięce w muzeum obozowym i kilka przez nas uratowanych wierszy żydowskiej poetki Poli Braun” (Archiwum Państwowe Muzeum na Majdanku. Sygn. VII/M-211, s. 8). 
ciał. Będę to pamiętał do końca życia. Ciała palone współtowarzyszy niedoli wykonywały ruchy wprost przerażające, nie dające się opisać. Dym ${ }^{29}$ i swąd palonych ciał odrzucały ${ }^{30}$.

Więźniowie, których zgładzono w piecach krematoryjnych, choć „fizycznie” byli w obozie nieobecni, przestali istnieć, trwali jednak w pamięci współwięźniów, zostawili po sobie - czasami niewyraźne - ślady, żyli anonimowo w cudzych wspomnieniach. Pamięć jest bowiem odporna na wszelkie techniki ludobójcze, nie są one w stanie jej unicestwić.

W relacji Zeewa Factora jak w soczewce skupiają się postawa wobec okupacyjnej rzeczywistości oraz wszystkie obszary strachu, wiary i nadziei, a także nastrojów Żydów:

Szczególnie biorąc pod uwagę, że widziałem piekło przed śmiercią, że byłem świadkiem, do czego ludzie są zdolni. I że byłem świadomy, że już nie będę mógł wymazać tego z pamięci! [...] zostałem wychowany na zasadach, które niestety okazały się niedużo warte. Nie sprawdziły się w praktycznym życiu. Sam fakt, że zabrakło pomocy bliźniego mówi niestety sam za siebie. [...] Jest bardzo źle! Radio Londyn nadało, że Niemcy wywożą całe pociągi węgierskich Żydów do Oświęcimia. Ja na to: „A co to jest Oświęcim?”. Rundbacken spojrzał mi w oczy mówiąc: „Ty nie wiesz, co to jest Oświęcim?!” [...] On powiedział mi zupełnie spokojnie, lodowato: „To jest to miejsce, dokąd oni biorą Żydów, trują ich gazem i spalają ich ciała" ${ }^{31}$.

Wiedza i świadomośćc ${ }^{32}$ Zagłady narastały stopniowo, ale też na różne sposoby były negowane. $Z$ analogiczną sytuacją „poznawania” prawdy o ludobójstwie mają do czynienia po kilkudziesięciu latach od zakończenia drugiej wojny światowej i jej ludobójczego wymiaru składający zeznania więźniowie oraz spisujący czy nagrywający relacje. Wydaje się, że czytając ich wspomnienia, uczestniczy się dzisiaj w swoistym projekcie przybliżania za pomocą peryfraz czy metafor rzeczywistości, w której kierowano się praktykami ludobójczymi.

${ }^{29}$ Niejako na marginesie warto zasygnalizować, że opisy palonych ciał i słupów dymu to interesujący temat dla studiów z ekokrytyki, która jest praktyką zaangażowaną, stanowi bowiem odpowiedź na kryzys ekologiczny. Szerzej: G. Garrard: Ecocriticism. New York 2004, s. 20-23; B. LaWrence: The Future of Environmental Criticism: Environmental Crisis and Literary Imagination. Massachusetts 2005; M. Tімотну: Dark Ecology: For a Logic of Future Coexistence. New York 2016; Tenże: The Ecological Thought. Massachusetts 2010; „Teksty Drugie” 2018, nr 2: Ekokrytyka; A. KŁos: Śmierć i rola trupów w „martwych przestrzeniach”. „Narracje o Zagładzie” 2016, nr 2, s. 163-201.

${ }^{30}$ Relacja Albina Obrzydowskiego (ur. 11 listopada 1927 r. w Warszawie). W: Relacje. T. 21. Archiwum Muzeum Stutthof, s. 189.

${ }^{31}$ Relacja Zeewa Factora..., s. 19, 22, 23.

${ }^{32}$ Por. J. Leociak: Nie('świadomość) Zagłady. W: Auschwitz a zbrodnie ludobójstwa w XX wieku. Red. A. Bartuś, P. Trojański. Oświęcim 2012, s. 87-103. 
Składający zeznania byli więźniowie lagrów, skracając dystans czasowy, wydobywają jakby z wnętrza tamtego świata wiedzę na temat okoliczności Zagłady i ówczesnego sposobu postrzegania genocydu.

Miałem wtedy osiemnaście lat, skamieniałem! Ale znając tego człowieka, wiedziałem, że na pewno nie opowiada mi bzdur [...] O Chełmnie nie słyszałem. Ja wiem, co to jest Chełmno, ale wcześniej o tym nie słyszałem. Wiedziałem jednak, że coś strasznego się dzieje, szczególnie jak dzieci wywieziono z getta i potem ich ubrania powróciły. [...] My przecież nie wyobrażaliśmy sobie, że Niemcy naszych dziadków, nasze babcie, nasze ciotki i nasze niemowlęta wysyłają na wczasy do Otwocka. Tego byliśmy pewni i wiedzieliśmy, że coś strasznego dzieje się, ale każdy odpychał od siebie te myśli [...] nie dawał wiary, że Niemcy są zdolni zrobić coś takiego. [...] Ale z chwilą, gdy przyjechaliśmy na stację, która się nazywała AUSCHWITZ (wiedziałem o tym, że Oświęcim nazywa się Auschwitzem) zrozumiałem, że nadszedł czas, żeby się pożegnać z matką, siostrą i ciotką ${ }^{33}$.

Wydaje się, że w przytoczonym fragmencie uchwycony został moment, kiedy do ocalonego dociera straszna prawda o Zagładzie, chwila, w której zaczyna on sobie zdawać sprawę z jej istnienia. Przebłysk śmierci. Jej presupozycja znajduje się w, znanej wówczas już dość dobrze, nazwie „Auschwitz”, która z czasem staje się metonimią ludobójstwa, a następnie przekraczającym rozmiary pojedynczego historycznego zdarzenia symbolem zła totalnego ${ }^{34}$.

O autorach przywołanych relacji można powiedzieć na pewno tyle, że próbując znaleźć odpowiednie, niekoniecznie wyraziste i zindywidualizowane określenie obozowych doświadczeń, zauważają także ich charakter nieindywidualny, odnoszący się do zbiorowości, działań kolektywnych. Dlatego też jedni ekspresywnie rekonstruują fakty i zdarzenia, ujawniają swoje emocje, chcą ciągle pamiętać, inni zaś starają się zdystansować, zapomnieć: „Droga usłana była trupami, które zamieć jak gdyby litując się szybko zasypywała śniegiem. W wyścigu ze śmiercią, która bez trudu nas dopędzała, dziesiątkując nasze szeregi, więźniowie tłoczyli się na wąskim skrawku piekła" ${ }^{35}$. Piekło okazuje się w tym przypadku metaforą jeszcze pojemniejszą niż Auschwitz - odsyła bowiem do zła, końca świata, ale i kwestii związanych z winą za grzechy, od której badacze Zagłady starali się niejednokrotnie dystansowaćs ${ }^{36}$.

Odłożone na archiwalne półki muzeów lagrowych niepublikowane zeznania, relacje i wspomnienia zawierają wiele jednostkowych historii ludzkich, opisa-

${ }^{33}$ Relacja Zeewa Factora..., s. 19, 22, 23.

34 Por. S. Herczyńska: Powrót na planetę Auschwitz. Zemdlenie Yehiela Dinura jako kluczowy moment $w$ tworzeniu pamięci o Zagładzie. „Narracje o Zagładzie” 2018, nr 4, s. 269-279.

${ }^{35}$ Oświadczenie więźnia nr 20485 Jana Szota. W: Relacje. T. 21..., s. 207.

${ }^{36}$ Por. M.R. Marnus: Holocaust. Historiografia. Przeł. A. Tomaszewska. Warszawa 1993, s. 13-14. 
nych szczegółowo bądź ledwie zarysowanych, układających się jednak koherentnie w przeraźliwy głos cierpiących narodów i pojedynczych ofiar ocalałych z ludobójstwa. Różnorodność tych świadectw o bólu i tragedii więźniów obozów koncentracyjnych - poza odmiennością samych opowiadających - wynika ze zróżnicowanej praktyki i taktyki dokonywania zbrodni w lagrach. Tym, co łączyło zeznających, była chęć przeżycia. Helena Jarocka zanotowała: „Całym jestestwem moim buntuję się przeciwko tej ohydnej przemocy... Ale trzeba wytrwać i przetrwać" ${ }^{37}$. Z analizowanych wypowiedzi nie wynika $\mathrm{w}$ zasadzie żadna świadomość terminologiczna świadków, nic, co pozwalałoby sądzić, że więźniowie obozów koncentracyjnych znali jakąś określoną lagersprachę ujednolicającą posługiwanie się słowem „ludobójstwo”. Sięga się więc po bardzo różne, najczęściej nienaukowe jego synonimy, pochodzące z języka potocznego, kręgów kulturowych, w jakich się poruszają więźniowie, z literatury ${ }^{38}$. Przeważa wśród nich nazwa najbardziej szczególnego miejsca - Auschwitz. Dla Żydów staje się ona symbolem ludobójstwa totalnego, wywołuje przerażenie, oznacza przeczuwaną wiedzę, jest równa nieomal pewności, że zaplanowana zbrodnia ma charakter masowy. O cytowanych świadectwach można na pewno powiedzieć: ich materią jest opis, a nie pojęciowe uchwycenie sytuacji. Nie posiada on może pożądanej z dzisiejszego punktu widzenia struktury terminologicznej, ma za to niezwykle mocny i prosty ładunek emocjonalny. Jego ramy tworzą fakty, nie retoryka.

\section{Bibliografia}

Adamczyк-Garbowska M., Duda H.: Terminy „Holocaust”, „Zagłada” i „Szoa” oraz ich konotacje leksykalno-kulturowe $w$ polszczyźnie potocznej $i w$ dyskursie naukowym. W: Żydzi i judaizm we wspótczesnych badaniach polskich. T. 3. Red. K. PilarCzyK. Kraków 2003, s. 237-253.

Assmann A.: Brzemię przeszłości. Przeł. A. Teperek. W: A. Assmann: Między historiq a pamięcią. Antologia. Red. nauk. i posłowie M. SARYusz-Wolska. Warszawa 2013, s. 199-207.

Bergen D.L.: Wojna i ludobójstwo. Krótka historia Holokaustu. Przeł. R. Witkowski, M. Sosnowski. Poznań 2011.

Bialocerkiewicz J.: Prawo międzynarodowe publiczne. Zarys wykładu. Toruń 2007. Daszkiewicz K.: Niemieckie ludobójstwo na narodzie polskim (1939-1945). Toruń 2009.

37 „Wspomnienia. Helena Jarocka. Z notatek lagrowych podczas pobytu w Gnewen - lager w Gniewinie - po ewakuacji Stutthofu". W: Wspomnienia. T. 10. Archiwum Muzeum Stutthof, s. 160.

${ }^{38}$ Por. A. Assmann: Brzemię przeszłości. Przeł. A. Teperek. W: A. Assmann: Między historiq a pamięcią. Antologia. Red. nauk. i posłowie M. SARYusz-WolsKa. Warszawa 2013, s. 199-207. 
Duszyński L.: Relacja z 15 kwietnia 1964 r. W: Relacje. T. 2. Archiwum Muzeum Stutthof, s. 112-139.

Garrard G.: Ecocriticism. New York 2004.

GŁowıŃski M.: Kapuściński: reportaż jako sztuka. W: „Życie jest z przenikania...”. Szkice o twórczości Ryszarda Kapuścinskiego. Zebrał i oprac. B. Wróblewski. Posłowie A. KapuścińsKa. Warszawa 2008, s. 63-66.

Gumкоwsкi J., KuŁAкоwsкi T.: Zbrodniarze hitlerowscy przed Najwyższym TrybunaŁem Narodowym. Warszawa 1961.

Herczyńska S.: Powrót na planetę Auschwitz. Zemdlenie Yehiela Dinura jako kluczowy moment $w$ tworzeniu pamięci o Zagładzie. „Narracje o Zagładzie” 2018, nr 4, s. $269-279$.

Herling-Grudziński G.: Inny świat. Zapiski sowieckie. Przedm. B. Russel. London 1953.

Jarzyna A.: Post-koiné. Studia o nieantropocentrycznych językach (poetyckich). Łódź 2019.

KŁos A.: Śmierć i rola trupów w „martwych przestrzeniach”. „Narracje o Zagładzie” 2016, nr 2, s. 163-201.

Lawrence B.: The Future of Environmental Criticism: Environmental Crisis and Literary Imagination. Massachusetts 2005.

LEMkin R.: Rządy państw Osi w okupowanej Europie. Prawa okupacyjne, analiza rzadzenia, propozycje zadośćuczynienia. Przeł. A. Bieńczyk-Missala i in. Warszawa 2013.

Leociak J.: Nie(świadomość) Zagłady. W: Auschwitz a zbrodnie ludobójstwa w XX wieku. Red. A. Bartuś, P. Trojański. Oświęcim 2012, s. 87-103.

Łотоска S.: „Ci, którzy działali na rozkaz” (relacja). Archiwum Państwowe Muzeum na Majdanku. Sygn. VII/Z-18, s. 1-9.

Marrus M.R.: Holocaust. Historiografia. Przeł. A. Tomaszewska. Warszawa 1993.

MoŁdawa M.: Gross-Rosen. Obóz koncentracyjny na Śląsku. Warszawa 1967.

Morawiec A.: Literatura polska wobec ludobójstwa. Rekonesans. Łódź 2018.

Nija кошsкi L.M.: Ludobójstwo. Historia i socjologia ludzkiej destrukcji. Warszawa 2018.

Oświadczenie więźnia nr 20485 Jana Szota. W: Relacje. T. 21. Archiwum Muzeum Stutthof, s. 205-210.

Piwińska E.: „Ruch oporu na polu kobiecym w obozie na Majdanku” (relacja). Archiwum Państwowe Muzeum na Majdanku. Sygn. VII/M-210, s. 1-37.

Protokół przesłuchania Danuty Brzosko-Mędryk z 1967 roku. Archiwum Państwowe Muzeum na Majdanku. Sygn. VII-135/160, s. 1-6.

Relacja Albina Obrzydowskiego. W: Relacje. T. 21. Archiwum Muzeum Stutthof, s. $174-192$.

Relacja Chaima Piotrowskiego. Państwowe Muzeum w Oświęcimiu. Nr inw. 174724. Sygn. Ośw./Piotrowski/3180, s. 1-8.

Relacja Zeewa Factora. Państwowe Muzeum w Oświęcimiu. Nr inw. 174723. Sygn. Ośw./ Factor/3179, s. 1-26.

„Teksty Drugie” 2018, nr 2: Ekokrytyka.

Тімотну M.: Dark Ecology: For a Logic of Future Coexistence. New York 2016.

Тімотну M.: The Ecological Thought. Massachusetts 2010. 
Tych F.: Długi cień Zagłady. Warszawa 1999.

WerebejCzy C C.: „Rozterki i rozczarowania. Wspomnienia z Polski. Czerwiec 1945kwiecień 1957”. W: Wspomnienia. T. 240. Państwowe Muzeum w Oświęcimiu. Nr inw. 181327. Sygn. Wsp./Werebejczyk/1374, s. 1-56.

Werebejczy к C.: „Wspomnienia z okresu Zagłady”. W: Wspomnienia. T. 240. Państwowe Muzeum w Oświęcimiu. Nr inw. 181327. Sygn. Wsp./Werebejczyk/1374, s. $1-63$.

Woliniewska M.: „Przeciw przemocy. Totalna zagłada i upodlenie śmierci” (zeznanie). Archiwum Państwowe Muzeum na Majdanku. Sygn. VII/M-211, s. 4-10.

„Wspomnienia. Helena Jarocka. Z notatek lagrowych podczas pobytu w Gnewen - lager w Gniewinie - po ewakuacji Stutthofu". W: Wspomnienia. T. 10. Archiwum Muzeum Stutthof.

Zakrzewski J.: „A my żyjemy dalej... Wspomnienia więźnia”. Archiwum Państwowe Muzeum na Majdanku. Sygn. VII/M-6, s. 22-39.

LuCyna SADZIKowsKa - dr hab., adiunkt w Instytucie Literaturoznawstwa Uniwersytetu Śląskiego w Katowicach. Członek redakcji rocznika naukowego „Narracje o Zagładzie” i zespołu redakcyjnego „Bibliotheca Nostra”. Z prof. dr hab. Krystyną Heską-Kwaśniewicz opracowała i wstępem opatrzyła Listy z Dachau. Gustaw Morcinek do siostry Teresy Morcinek, które były nominowane do Nagród Historycznych „Polityki” w kategorii wydawnictw źródłowych. W 2017 roku wydała książkę Szukanie kluczy. O literaturze poobozowej Gustawa Morcinka, a w 2019 monografię Listy z lagrów i więzień. 1939-1945. Wybrane zagadnienia. Również w 2019 roku ukazała się publikacja Działalność poselska Gustawa Morcinka, czyli katalog ludzkiej biedy. Dokumenty w opracowaniu Krystyny Heskiej-Kwaśniewicz i Lucyny Sadzikowskiej. 